\title{
The Framework of Racism in Toni Morrison's The Bluest Eye: A Psychosocial Interpretation
}

\author{
Md. Reza Hassan Khan \\ Lecturer, Department of English \\ Bangladesh University of Business and Technology (BUBT) \\ Dhaka Commerce College Road, Mirpur-2, Dhaka-1216, Bangladesh \\ E-mail: rezahassankhan@gmail.com \\ Md. Shafiqur Rahman \\ Lecturer, Department of English \\ Dhaka Commerce College, Dhaka \\ Mirpur-2, Dhaka-1216, Bangladesh \\ E-mail: shafiqur.rahman1983@gmail.com
}

Doi:10.7575/aiac.alls.v.5n.2p.25

Received: 10/02/2014

URL: http://dx.doi.org/10.7575/aiac.alls.v.5n.2p.25

Accepted: 22/03/2014

\begin{abstract}
In The Bluest Eye, Toni Morrison presents a community in which a racist ideology is internalized. The sufferers of racial abuse in this community both endure and resist in a complex inverse interrelationship between the two actions. This contradiction of the internalization and the insurrection of racial abuse is one of the crucial characteristics of this community which is best comprehended if looked at from both a Marxist and a psychoanalytic point of view. The objective of the paper is to have a look at the politics of postmodern consumer culture of capitalism in a racist community. At the same time, the paper aims at tracing the sadomasochist attitude of the characters in this framework of internalized racism in the African-American community of The Bluest Eye.
\end{abstract}

Keywords: racist ideology, whiteness, capitalism, perverse racism, sadomasochism

\section{Introduction}

One of the key features of Toni Morrison's The Bluest Eye is revealing the interrelation of the internalization and the resistance of racial abuse in a postmodern community. The connection between capitalism with obsessive and perverse racial and sexual systems best demonstrates this contradictory interrelation. The nature of such interrelations among ethnocentrism, racism and sexism in The Bluest Eye becomes obvious if investigated from both a Marxist and a psychoanalytic point of view. This paper will attempt to trace the manner, from a Marxist and psychoanalytic viewpoint, in which the subjects of racial bias in The Bluest Eye both endure and resist at the same time. Much work has been done on this famous novel so far. A work by Patrice Bryce (1992) explores how cultural and communal traditions influence the search for self and place within a given African-American community. Ogunyemi (1977) deals with the triadic patterns used in the novel in portraying the tragic condition of blacks in a racist America. Colson (2006) tries to reveal ways that the novel explores themes of race and identity. Klotman (1979) focuses on the two black families, the McTeers and the Breedloves, and tries to relate the African-American reality to the 'Dick-and-Jane and the Shirley Temple sensibility' in The Bluest Eye. In Rosenberg's (1987) work we find the black girlhood in the racist AfroAmerican community which explained how, in spite of immense obstacles, one might fashion a self in the structure of racism. Fisher and Silber (2003) offers a nice analysis of female experience and female subjectivity looking at them through the lens of gender. Cormier (1994) shows how Toni Morrison presents the Black Naturalism in which the characters create a racial self-hatred and thus moves far and far away from self-love. This work shows how postmodern consumer culture uses money, power and prestige issues to turn blacks against blacks 'creating an aberrant community, whose little boys and girls sing songs of self-hatred'. In another study, Vickroy (2002) uses postcolonial, and object relations theories to illuminate the cultural aspects of traumatic experience that shape relationships, identity formation, and the possibilities for symbolization in The Bluest Eye. These works on The Bluest Eye discuss, in various ways, the trauma and self-hatred that the existing framework of racism in the Afro-American society is able to produce. But the relation between the impacts of the postmodern consumer culture with the complex psychodynamics of the black characters in The Bluest Eye has not been focused much, which could have been a more comprehensive way to understand the framework of racism in the African-American society. This paper aims at looking through the lenses of both Marxism and psychoanalysis to bring out the nature of this existing framework of racism in the African-American community depicted in The Bluest Eye. 


\section{Discussion}

\subsection{Racism and Capitalism}

In The Bluest Eye, Toni Morrison demonstrates the connection between capitalism and the construction of desire in the community when she points out the basic components of the society and media like commercials, literary works, kid's toys etc. Capitalism in a postmodern society typically hinges on manufacturing new utilities and desires to function within a racist domain. In this domain, the racist idealization of whiteness has intense sexual and economic associations. If we closely review the adoration of whiteness in the society portrayed in The Bluest Eye, we notice the bond between capitalism and racism. The Bluest Eye reveals just how the patterns of internalized racism utilize the authority of postmodern capitalism, its power and methods of representation like kids gadgets, advertisements etc. to create unconscious desires and fears; and illustrates this interconnection between beauty, racism, and capitalism in numerous incidents narrated in the novel. A good example is Claudia's splitting up the Raggedy Ann doll. She actually attempts to dissect the core of the framework of racism through ripping it apart: "I had only one desire: to dismember it. To see of what it was made, to discover the dearness, to find the beauty, the desirability that had escaped only me" (Bluest Eye 20). Claudia defies the adoration of white beauty that has been put into practice by commercials, a tool of postmodern capitalism, to produce desire for it. But she fails to understand the politics of socially engineered idealization, and wrongly locates it inside the material object, that is, the doll.

\subsection{Beauty Industry and Ideology}

Racism is always built upon socially fabricated values. Claudia's perplexity concerning the representation of beauty refers to that politics. This also is associated with Freud's idea of the unconscious treatment of words as real things (Freud, "The Unconscious" 147). This is why Claudia tries to transform symbolic representation of the doll's beauty into the real and cannot accept it as a form of external representation.

When it comes to cinema, according to Jean Louis Baudry, we see a similar transformation of the symbolic codes into real properties. Such representations are often incorrectly recognized as perceptions in the postmodern consumer community ("The Apparatus" 315). In The Bluest Eye, television and movie both play a crucial role in modifying the framework of internalized racism using such make-believe representations as genuine impressions. Pauline is swayed by the idea of beauty and ideal love when she finds them as perceptions from movies.

Morrison here shows how the notion of 'beauty' can be manipulated by popular media and film to produce racist self hatred by compelling females feel insecure and awful about their figure and color. The ideology of all the characters in The Bluest Eye is influenced pretty much by such idealization of whiteness as beauty in a consumer community. In Pauline's case, "she was never able, after her education in the movies, to look at a face and not assign it some category in the scale of absolute beauty" (Bluest Eye 122). In another context, the female-to-female relationship turns out to be further complicated when the heterosexual desire is mediated by it. Inside this politics of 'beauty industry', women are entirely commoditized and considered as mere objects of desire. Blackness ends up being a form of economic incapacity. In The Bluest Eye, Morrison repeatedly demonstrates, and draws our attention to the prevailing idea that the poverty and blackness of the Breedlove family is related to their economic incapacity, and Pecola is the fundamental embodiment of ugliness related to this economic incapacity.

\subsection{Rejection of the ego and subjectivity}

As these black people do not possess a place in the domain of white beauty, they derive a complicated impression of beauty from humiliating people of their own community. In this way Pecola and her family turn out to be the focal point of the whole community's self hatred. Moreover, by indicating that Pecola's ugliness help everyone else feel beautiful, and her weakness make others feel potent, Morrison tries to reveal how such idealization predominantly depends on the degradation of an 'Other'.

Throughout The Bluest Eye, Pecola Breedlove becomes a revalorized entity not just for the whites but also for the blacks. She turns out to be the embodiment of failure both racially and economically when she tries to buy a candy from a white American male. He looks at her:

Somewhere between retina and object, vision and view, his eyes draw back, hesitate, and hover. At some fixed point in time and space he senses the need not to waste the effort of a glance. He does not see her, because for him there is nothing to see. (Bluest Eye 48)

Thus her ego lacks any sort of validation in the eye of the 'Other' as her existence is totally unrecognized; she is crushed into an instance of self defiance, a vacuum signifying nothing, a total absence of acknowledgment as a human being. Pecola knows very well how this failure of her ego is related to her blackness: "All things in her are in flux and anticipation. But her blackness is static and dread. And it is the blackness that accounts for, that creates, the vacuum edged with distaste in white eyes" (Bluest Eye 49).

Not only she is despised for being black, but her blackness also results in being the fixed object of a perpetual gaze of the white men which forces her presence into the position of an object of cultural desire detrimentally. Under this constant gaze the ego of the black girl is completely shattered and she is forced to feel awful for her color, her body, even for her whole existence. She knows that the whole community has its eye on her even when she is alone. She creates a new, imaginary concept of 'self' which she finds in the eyes of the other people, and she begins to believe that image, as in a mirror, to be her true self. When she becomes pregnant, this image gets associated with a sense of perverse sexism and guilt. This guilt is directly related to the blackness of Pecola and her family. In fact, she turns out to 
be a symbol of 'guilt' and 'ugliness' in the eye of the community. In a complex way the community needs this image of hers to feel better in comparison to her debased position. Pecola's blackness and pregnancy both serve this purpose. This further validates the idea of white beauty through self defiance.

This concentration on the gaze of the white man shows how subjects are maneuvered not only on an imaginary level but also on a visual level. Pecola desires to have a pair of blue eyes, because she has a delusional belief that if she obtains blue eyes she will be beautiful and can reverse the relationship that reduced her to a hollow image in the eyes of the white 'Other'. This obsessive desire ends up in a psychotic attempt to a total denial of her existence: "'Please God,' she whispered into the palm of her hand. 'Please make me disappear.' She squeezed her eye shut. Little parts of her body faded away" (Bluest Eye 45). This suggests an almost psychotic withdrawal from the domain of representations through the denial of subjectivity and body.

\subsection{Internalized Racism and the 'Other'}

As mentioned by Freud, the subject's psychological world is shattered and later re-created in an imaginary, unreal fantasy in the first phase of psychosis (The Unconscious, 147). In Pecola's instance, we notice the very same thing as she first makes an effort to destroy her identity as a black subject, and then pose an obsessive attempt to obtain blue eyes. This blackness and psychotic desire to obtain blue eyes have a relationship with the socioeconomic incapacity of Pecola's family, as their homelessness brings them down as nonhuman objects. According to Lacan (2013), 'The-nameof-the-father' links the real order with the symbolic order. But in psychosis, the subject can no longer deal with 'thename-of-the-father'. Once this relationship is torn apart, the subject is then manipulated by the discourse of the 'Other'. In Pecola's case, her family's economic condition together with her blackness both eliminates her from the central symbolic order of white consumer culture.

In the framework of racism, the middle class African-Americans accept the represented associations between blackness and excessive sexuality. According to Davis Charles, one of the primary manifestations of developing 'obsessive neurosis' is the desire to repress the irrepressible sexuality through sophistication and differentiation (Slave's Narrative 1985). Such a form of 'obsessive neurosis' is exposed by Toni Morrison in the character of Geraldine. This stems forward from an obsessive effort to stay in line with the predominant social 'Other'. Thus Morrison gives a psychoanalytic layout of the internalized racism of Geraldine's class. The racist mindset of Geraldine's class, the accepted interconnection between blackness and over sexuality, and a strong urge to stay separated from any sense of sullied blackness is associated with an obsessive fear which turns them into 'obsessive stereotypes' whose only thought is to renounce blackness by any means. But when this obsessive desire falters, it does not destroy the racist mindset; rather further tones up into a dejection resulting in deeper obsessive delusions. We find it in Geraldine's obsessive attempt to turn the skin of her son white:

In the winter his mother put Jergens Lotion on his face to keep the skin from becoming ashen. Even though he was light-skinned, it was possible to ash. The line between color and nigger was not always clear; subtle and telltale signs threatened to erode it, and the watch had to be constant. (Bluest Eye 87)

In the long run, this obsessive fear of any indication of blackness isolates Geraldine from her own community. Thus the psychological hierarchy of the middle class blacks is fed by racist behavior producing from their obsessive fear of discovering themselves in the realm of the terrifying real. This obsessive fear compels them to surrender to the racist discourse established by the 'Other'.

\subsection{Obsession, Perverse Racism and Fear of Castration}

Not just a middle class African-American society which is deeply entangled by diverse modes of racist attitude, but the upper class also plays its role in the framework of racism in The Bluest Eye. Soaphead Church's father who is 'a mulatto bastard' born of a 'decaying British Nobleman' was obsessed with his whiteness and afterwards was wedded to a woman who internalized the same ideology. The consequence of this 'Anglophilia' is the communal worship of a crucial signifier connecting both whiteness and aristocracy.

In Soapead's grandfather's instance, the agonizing confrontation of black sexual experience resulted as subjective divisions in the following generations and a sense of communal worship of whiteness is formed among them. According to Seshadri-Crooks (2002), this is symptomatic of the hysterical neurotic racism as described by Lacan.

Illustrating the perverse expressions of psychological disorders in The Bluest Eye, Toni Morrison tries to portray the fundamental framework of the internalized racism in the African-American community. In this racial discourse, one must consistently demonstrate and testify his whiteness out of the fear of not feeling perfectly white. This endeavor is further noticed in the delineation of a perverse form of internalized racism which is searching for a white identity. Soaphead Church and Cholly Breadlove are the ideal examples of how these types of perverse racists transmit their own humiliation onto the society.

According to Freud, in such perverse circumstances, the subject identifies himself with his father and performs the role of the father unconsciously (On Sexuality, 345). This is derived from an attempt to master the fear of castration but eventually results in the castration of a feminized 'Other' just as Lacan relates the perverse sexism of the fetish child who identifies himself with the sadist father resulting in the projection of 'lack' into the domain of the 'Other' (Seminar I, 1988).This theory explains why and how Soaphead Church projects his very own fear of blackness and of castration onto young girls by raping them. For him, Pecola's blackness is straightly correlated to her low social status. Pecola is "a little black girl who wanted to rise up out of the pit of her blackness and see the world with blue eyes" (174). Thus, 
his abuse of the little girl recreates his own past; and he makes an attempt to escape his own corruption and sense of guilt by displacing it onto the act of corrupting others.

With regards to Cholly, Pecola's father, he was accidentally found by two white men while he was indulged in a sexual act. They found him and forced him to go on having sex with the black girl he was with. This distressing experience stimulated his rape of his own daughter. When Cholly was forced to have sexual intercourse before the white men's watching eyes and flashlight, he projected his hatred not onto them, rather onto the girl he was with. This was an act of displacement of the repressed fears, anger and anxieties in Cholly's mind. This displacement of humiliation and anger has the same root as in Soaphead Church's case. Both Cholly and Soaphead Church use sex to master past traumas by reproducing them in different circumstances.

Cholly rapes Pecola as she stands for his own failure to become a father, and to shield himself against the fangs of the framework of racism. Choly finds Pecola resembling her mother a lot. Pecola's resemblance with Pauline is yet another reason that pushes Cholly to rape his very own daughter. This implies that the Cholly's perverse sexuality is related to repetition of the past pains and to an unconscious effort to master the humiliation of his own sexuality. On the other hand, we find Pauline Breedlove in a strange masochistic structure where blackness becomes symbol of a sense of martyrdom and sacrifice, the base of her all 'goodness'. This fabricated sense of goodness needs, in a perverted way, the sins of her husband to be glorified. Without Cholly being what he is, Pauline cannot feel completely glorified in her position.

If Cholly had stopped drinking, she would never have forgiven Jesus. She needed Cholly's sins desperately. The lower he sank, the wilder and more irresponsible he became, the more splendid she and her task became. (Bluest Eye 42)

Through the portrayal of all these sadomasochistic characters, Morrison reveals how they tend to obtain a symbolic logic through perversion. In such a framework of perversion, Cholly's hatred for his wife and his own low self image is displaced onto his attempts to destroying the subjectivity of his daughter and wife with violence.

\section{Conclusion}

Crafting multiple facets of subjective reality, The Bluest Eye shows how in the framework of an internalized racism all its components affect each other to produce a set of prejudices in which the sufferers both endure and resist simultaneously. This set of prejudices incorporates psychotic perversion where the subject endures and then makes an attempt to resist by deleting the fragmented image of the 'self' projecting the hatred onto the object. On the other hand, in the case of perversion in a racial discourse, Toni Morrison also shows us how the suffering subjects desire to identify with the inconceivable, idealized whiteness. In such a framework of internalized racism, the victims are either sadomasochistic or delusional in their effort to defy the capitalist machine of racial subjugation.

\section{References}

Baudry, J.L. (1986). "The Apparatus: Metaphysical Approaches to the Impression of Reality in Cinema." Narrative, Apparatus, Ideology. Columbia UP. 299-318.

Bryce, Patrice. 1992. The Novels of Toni Morrison: The search for self and place within the Community. New York: Peter Lang.

Colson, M. (2006). The Story Behind Toni Morrison's The Bluest Eye. Heinemann-Raintree Library.

Cormier-Hamilton, P. (1994). Black Naturalism and Toni Morrison: The Journey Away from Self-Love in The Bluest Eye. Melus, 109-127.

Fisher, J., \& Silber, E. S. (Eds.). (2003). Women in literature: reading through the lens of gender. Greenwood Publishing Group.

Freud, S. (1963). "The Unconscious". The Essentials of Psychoanalysis. 142.

Klotman, P. R. (1979, December). Dick-and-Jane and the Shirley Temple sensibility in The bluest eye. In Black American Literature Forum (pp. 123-125). School of Education, Indiana State University.

Lacan, J., Miller, J. A. E., \& Grigg, R. T. (1993). The seminar of Jacques Lacan, Book 3: The psychoses 19551956. In Translation of the seminar that Lacan delivered to the Société Française de Psychoanalyse over the course of the academic year 1955-1956.. WW Norton \& Co.

Ogunyemi, C. O. (1977). Order and Disorder in Toni Morrison's The Bluest Eye. Critique: Studies in Contemporary Fiction, 19(1), 112-120.

Rosenberg, R. (1987, December). Seeds in hard ground: Black girlhood in The Bluest Eye. In Black American Literature Forum (pp. 435-445). Indiana State University.

Seshadri-Crooks, K. (2002). Desiring whiteness: a Lacanian analysis of race. Routledge.

Morrison, T. (1970). The Bluest Eye. Penguin.

Vickroy, L. (2002). Trauma and survival in contemporary fiction. University of Virginia Press. 